Churilova, E., Salin, V., Shpakovskaia, E., \& Sitnikova, O. (2019). Influence of

world social and economic indicators' interlinkage on the development of

human potential. Journal of International Studies, 12(4), 79-99.

doi:10.14254/2071-8330.2019/12-4/6

\title{
Influence of world social and economic indicators' interlinkage on the development of human potential
}

\section{Elvira Y. Churilova}

Department of Accounting, Analysis and Audit, Financial University under the Government of the Russian

Federation,

Moscow, Russia

EChurilova@fa.ru

\section{Viktor N. Salin}

Department of Accounting, Analysis and Audit,

Financial University under the Government of the Russian

Federation,

Moscow, Russia

salvini@rambler.ru

\section{Elena P. Shpakovskaia}

Department of Accounting, Analysis and Audit,

Financial University under the Government of the Russian

Federation,

Moscow, Russia

epsh51@mail.ru

\section{Oksana Yu. Sitnikova}

Department of Accounting, Analysis and Audit,

Financial University under the Government of the Russian

Federation,

Moscow, Russia

xenia-s@mail.ru

Abstract. 1) The paper deals with the links between the following indicators: Human Development Index; Human Development Index adjusted for socioeconomic inequality; Gender-related Development Index; Gender Inequality Index; Prosperity Index; Education Index; Happy Planet Index; Gini Index; PPP-based measures of GDP per capita. The Prosperity and "Happiness" Index belongs to the new generation of statistical indicators, which allows ranking countries according to their socioeconomic status. Determination of how these indices agree with each other and the Human Development Index 
and methodologically do not contradict each other is one of the objectives of the study conducted, the results of which are discussed in this article. 2) The article shows the results of the multidimensional classification of the countries into homogeneous groups on the basis of cluster analysis. Within these groups, the prospects for changing the Human Development Index and other indicators involved in the analysis in the future have been considered. The article provides the regression models of the dependency of indicators and their correlation matrices for each group of countries. 3) The results of the study allowed the authors provide specific recommendations on the growth of Human Development Index for each country group separately. 4) Assessment of country's human potential is one of the most important socioeconomic problems in contemporary science and practice. Further technological progress of the whole world and of individual countries depends on the conditions of human potential development in today's world.

Keywords: Human Development Index, Human Development Index Adjusted To Reflect Inequality, Gender-related Development Index, Gender Inequality Index, Legatum Prosperity Index, Education Index, Happy Planet Index, multivariate statistical analysis, cluster analysis, correlation analysis, regression analysis.

JEL Classification: J180, P5, D630, I38

\section{INTRODUCTION}

Sustainable innovative development of states in contemporary world is directly related to the degree of their human factor development. The Sustainable Development Goals (SDGs) is the largest global partnership agreement and development plan for the planet ever made. It was agreed upon by all the UN member states in September 2015 and consists of 17 goals and 169 targets. The goals ultimately aspire to create a better, more inclusive and more prosperous world by 2030 (Unleash, 2019). If earlier the welfare of a country and the size of its national wealth were determined largely by its material resources, then in the XXIst century the intangible achievements, the size of which depends on the degree of people's education and their socioeconomic status, have come into focus.

The purposes of this study are as follows:

- to identify how the indices used for countries' ranking on various socioeconomic fields, reconcile, i.e.

to determine the degree of objectivity of the considered indices and the interlinkage between them;

- to classify countries into homogeneous groups according to the considered indicators and then to define the interlinkage between them;

- to provide specific recommendations on the development of human potential in the countries included in each group on the basis of the results of this study.

The data used was complete and comparable only for 132 countries, which were thus selected for analysis. However, the resulting sample can be considered as sufficiently complete and representative. As uncovered by the study, some of the countries are either too small (small population, small area, low GDP etc.), so their influence on the world average is insignificant and can be neglected; or the countries can be considered from the statistical point of view as outliers, anomalous observations. Such countries are, for example, Cuba or Syria, as they have complex and atypical political and economic situation. 


\section{LITERATURE REVIEW}

"Human development is about human freedoms. It is about building human capabilities-not just for a few, not even for most, but for everyone. In 1990, UNDP published the first Human Development Report (HDR). Since then, it has produced more than 800 global, regional, national and subnational HDRs and organized hundreds of workshops, conferences and other outreach initiatives to foster human development. It is 28 years since the launch of the first HDR, and new challenges to human development, especially inequality and sustainability, require concerted measurement and analytical attention. Data availability is expanding with new opportunities for measurement innovation and disaggregation and possibilities for new partnerships growing out of the 2030 Agenda for Sustainable Development"(UNDP, 2018b).

The question of why some developing countries have lower social welfare, despite the high-income growth, was considered by Jones \& Klenow (2016). They give a proved explanation that in developing countries the average life expectancy is comparatively shorter, and in society, there is a high inequality. Developing countries increased their share in manufacturing exports but saw little expansion in agricultural exports, barely maintaining their share of around one-third of global trade (after losing market shares during the 1980s). Such trends in globalization inevitably impact the poor in developing economies. (Desai \& Rudra, 2018)

Ranis, Suri and Frances (2011) used the strategy of panel data to summarize the interlinkage between economic growth and human development. Empirical results show that early attention to human development leads to sustainable economic growth (Weil, 2013). In addition, long-term strong economic growth not accompanied by human development, cannot lead to a stable equilibrium. At the same time, they also note that the ratio of social spending and income distribution are valuable for the improvement of human development as a strong human development is a necessary condition in order to bring any country to a virtuous circle (Stock \& Watson, 2014; Latyshev \& Akhmetshin, 2015).

Higher economic resources, but devoid of social indicators, are also discussed by Lind \& Moene (2009). They point out that there is no connection between the original avarice and subsequent economic growth. Many countries with higher growth tend to have poor development (Income Gini coefficient, $\mathrm{n} / \mathrm{d}$ ).

To the integrated inequality with the Human Potential Development Index scientists have made a significant contribution and proposed to reduce the disparities of each index dimension (Barro\& Xavier, 2012; Benjamin,2016). Inequality in human development appears to be clearly negatively associated with the average level of human development. However, for GDP per capita, the positive attitude, reasonable for the attainment of education and very weak for life expectancy at birth. Moreover, the linkage also has the shape of an inverted U (Berg \& Ostry, 2011; Clark \& Senik, 2016). GDP growth is associated with increased life expectancy and macroeconomic stability. William Easterly (1999) used a dataset of 81 indicators covering 4 different time periods, and his results show that economic growth has a positive and significant impact on life. Several empirical results show that economic growth has improved the public health system, resulting in reduced infant mortality and increased schooling level (Zhang et al., 2010).

Analyzing low, medium and rich countries, the empirical result showed that inequality in human development within countries is very high, especially in countries of Africa to the South of the Sahara. In addition, income inequality is usually higher than inequality in education and life expectancy. Moreover, the empirical result shows that the level of inequality is weakly associated with the Human Potential Development Index (The Legatum Prosperty Index, 2017). 
Analyzing the relationship of economic growth to inequality, X. Zhang, J. Yang and S. Wang (2010) found out that economic growth rate will first increase with the growth of income inequality before the growth rate will decrease with inequality.

\section{METHODOLOGY}

\subsection{General methods}

To achieve the work objectives the main methods of the multivariate statistical analysis were applied: cluster, correlation and regression analyses. Cluster analysis was carried out in STATISTICA software package by distinct from each other methods for a different number of groups. However, the best option was the classification by the "k-means" method using the "Sort distances and take observations at constant intervals" procedure into 8 groups as having the highest inter-group variance between the obtained clusters (see Table 3). As the indicators have different units of measurement, before conducting cluster analysis, they were standardized (Pritchett, 2013).

The work examined the links between the following indicators, directly determining the status and human development of the country: Human Development Index; Human Development Index adjusted for socio-economic inequality; Gender-related Development Index; Gender Inequality Index; Prosperity Index; Education Index; Happy Planet Index; Gini Index; PPP-based measures of GDP per capita (Hanushek, 2013).

\subsection{The indicators used in the analysis}

Human Development Index (before - 2013 "Human Potential Development Index") -integral index, developed by experts of the United Nations Development Programme (UNDP) in 1990, characterizing the human development in different countries (Happy Planet Index, 2016). The index is calculated annually and is used in the analytical reports of the United Nations about the prospects for human development. Since 2010, UN experts also calculated Human Development Index adjusted for socioeconomic inequality (UNDP, 2018a).

Gender-related Development Index, GDI is a measure of human development according to the same criteria as the human development index. The difference is that the greater is the difference in the components of the Human Development Index indicators separately for men and women, the lower the GDI is. Gender-related Development Index is defined by the UN experts and presented in the Report on Human Development (Gender Development Index, n/d.).

Used in the work the Gender Inequality Index, in turn, reflects the inequalities in social and economic achievements of men and women. This index was first presented by the Secretariat of the World Economic Forum in Geneva in 2010. At this time, it is being used by the United Nations, when characterising the human development in different countries of the world (Gender Inequality Index, n/d.).

The Prosperity Index of world countries of Legatum Institute (The Legatum Prosperity Index) composite index, which characterizes the achievements of various countries in terms of welfare and prosperity (The Legatum Prosperity Index, 2017). For the first time, this index was calculated in 2006 by British analytical centre The Legatum Institute. The study evaluated its linkage with other variables involved in the analysis (Grimm et al., 2010).

The Education Index is the integral indicator of the United Nations Development Programme (UNDP), which is one of the main indicators of social development of populations in the world. This 
index describes the country's achievements, in terms of educational attainment, so its participation in this study was logical (Education index, $\mathrm{n} / \mathrm{d}$.).

One of the most "exotic" indicators, which were considered in the study, is the Happy Planet Index on the basis of which you can assess the "real" welfare of the population of the country and its environment. First, the index was calculated in 2006 by the New Economics Foundation. However, the methodology of its calculation has some scientific criticism, in particular, it reflects rather the economic welfare of the people, while, the person feels happy or unhappy at the different level of material wealth (Happy Planet Index, 2016).

In international statistics, the Gini Index is used to evaluate the degree of stratification of the population by income level (annual). We used the Gini Index (the Gini coefficient, transferred into a percentage).

Also, the analysis considered the PPP-based measures of GDP per capita (GDP) - gross domestic product per capita at purchasing power parity. The indicator determines the level of economic development of the country and expressed in the US dollar of FRS (Weisbrot \& Ray, 2010).

In the basis of calculation of the considered indices are the following indicators (see Table 1):

Table 1

The indicators used in the analysis

\begin{tabular}{|c|c|c|}
\hline Index Name & Abbreviation & Indicators used to calculate the index \\
\hline $\begin{array}{l}\text { Human Development } \\
\text { Index }\end{array}$ & HDI & $\begin{array}{l}\text { - life expectancy; } \\
\text { - the average duration of training in years; } \\
\text { - expected duration of training of the population, still receiving education; } \\
\text { - GNI per capita at PPP in USD }\end{array}$ \\
\hline $\begin{array}{l}\text { Human development } \\
\text { index adjusted for } \\
\text { inequality (Human } \\
\text { development index } \\
\text { adjusted to reflect } \\
\text { inequality) }\end{array}$ & HDII & $\begin{array}{l}\text { - life expectancy; } \\
\text { - the average duration of training in years; } \\
\text { - expected duration of training of the population, still receiving education; } \\
\text { - GNI per capita at PPP in USD; } \\
\text { - the differentiation coefficient of the Human Development Index; the } \\
\text { differentiation coefficient of Health (Longevity) Index; } \\
\text { - the differentiation coefficient of the Education Index; } \\
\text { - the differentiation coefficient of the Income Index; } \\
\text { - the differentiation coefficient of the Mortality Index; }\end{array}$ \\
\hline $\begin{array}{c}\text { Gender-related } \\
\text { Development Index }\end{array}$ & GDI & $\begin{array}{l}\text { - life expectancy (separately for men and women); } \\
\text { - the average duration of training in years (separately for men and women); } \\
\text { - expected duration of training of the population, still receiving education, } \\
\text { in years (separately for men and women); } \\
\text { - GNI per capita at PPP in USD (separately for men and women); }\end{array}$ \\
\hline $\begin{array}{l}\text { Gender Inequality } \\
\text { Index }\end{array}$ & GII & $\begin{array}{l}\text { - Maternal Mortality Index; } \\
\text { - Adolescents Birthrate } \\
\text { - the female and male population with at least secondary education; } \\
\text { - the share of seats in Parliament held by men and women; } \\
\text { - the economic activity rates of female and male population }\end{array}$ \\
\hline $\begin{array}{l}\text { Prosperity index of } \\
\text { the Legatum Institute } \\
\text { (The Legatum } \\
\text { Prosperity Index) } \\
\end{array}$ & LPI & $\begin{array}{l}\text { - The combined indexes in nine categories: economics, entrepreneurship, } \\
\text { management, education, healthcare, security, personal freedom, social } \\
\text { capital, ecology. }\end{array}$ \\
\hline Education Index & El & - The Adult Literacy Index (2/3 of weight) \\
\hline
\end{tabular}




\begin{tabular}{|c|c|c|}
\hline & & $\begin{array}{l}\text { - The index of an aggregate share of students obtaining primary, secondary } \\
\text { and higher education ( } 1 / 3 \text { weight })\end{array}$ \\
\hline $\begin{array}{c}\text { The Happy Index of } \\
\text { International research } \\
\text { centre Gallup (Gallup } \\
\text { International)Happy } \\
\text { Planet Index }\end{array}$ & HPI & $\begin{array}{l}\text { - GDP per capita; } \\
\text { - life expectancy; } \\
\text { - the presence of civil liberties; } \\
\text { - a sense of security and confidence in the future, } \\
\text { - the stability of families, } \\
\text { - the employment, } \\
\text { - the corruption level, } \\
\text { - the level of trust in society, } \\
\text { - the results of public opinion polls of residents of different countries about } \\
\text { how happy they feel themselves. }\end{array}$ \\
\hline Gini Index & GI & - The annual income level of the population \\
\hline
\end{tabular}

Source: Compiled by the author based on sources: http://hdr.undp.org/en/content/human-development-index-hdi; http://hdr.undp.org/en/content/gender-development-index-gdi; http://hdr.undp.org/en/content/genderinequality-index-gii; https://www.prosperity.com; http://hdr.undp.org/en/content/education-index; http://happyplanetindex.org/countries/;

http://hdr.undp.org/en/content/income-gini-coefficient https://unstats.un.org/UNSD/snaama/dnllist.asp;

If you look to the tabulation to the indicators that are the basis for the index's calculation (see Table. 1), you see that most of them are based on indicators that are heavily dependent upon expert evaluations and subjective reasons. For example, the indicator of the presence of civil liberties is an inherently subjective indicator, since the understanding of what is the "civil liberties" in countries with a different religious way of life is conventional and subjective. For Europeans such civil liberties as "permit women to sue for divorce with her husband" is not freedom in its essence, this fact reveals inself within their ordinary life. For Europeans, it is incomprehensible how it may be the opposite. While for Saudi Arabia is, of course, is big civil liberty (Lind \& Moene, 2009).

Another example, the indicator "how happy the people feel" is also totally subjective, mostly it depends on the national psychology of the people. So, in the United States it is considered indecent to plead yourselves unsuccessful and unhappy, while in Russia, a man might say that he is dissatisfied with his life than happy because traditionally to flaunt one's prosperous life is not accepted.

Also, considering the World Happiness Report 2019 from the UN's Sustainable Development Solutions Network (UNSD Solutions Network, 2019) is particularly interesting as it ranks 156 countries by how happy their citizens perceive themselves to be. Its rankings are not an index, the report is without a scientific basis. The report principally relies on asking a straightforward, subjective question of more than 1,000 people in more than 150 countries: "Imagine a ladder, with steps numbered from 0 at the bottom to 10 at the top. The top of the ladder represents the best possible life for you and the bottom of the ladder represents the worst possible life for you. On which step of the ladder would you say you personally feel you stand at this time?" Finland takes the top spot once again as the happiest country in the world. Rounding out the rest of the top 10 are countries that have consistently ranked among the happiest. They are in order: Denmark, Norway, Iceland, Netherlands, Switzerland, Sweden, New Zealand, Canada and Austria. The UK is ranked 16th, gaining three spots from 19th last year, while the US is ranked 19th, dropping one spot from last year. The troubled African state of South Sudan is ranked the least happy country in the world. The rest of the bottom five comprise Central African Republic, Afghanistan, Tanzania and Rwanda. Unsurprisingly, there is a strong correlation between unhappiness and the poorest and most dangerous countries. 


\section{EMPIRICAL RESULTS AND DISCUSSION}

The calculated statistical characteristics of indicators for all countries as a whole are shown in Table 2.

Table 2

Statistical characteristics of the studied indicators for the whole set of countries

\begin{tabular}{|c|c|c|c|c|}
\hline \multirow{2}{*}{ Variable } & \multicolumn{4}{|c|}{ Descriptive Statistics } \\
\cline { 2 - 5 } & Mean & Minimum & Maximum & Coefficient Variation \\
\hline HDI & 0.69 & 0.35 & 0.95 & 23.10 \\
\hline HDII & 0.56 & 0.20 & 0.90 & 34.14 \\
\hline GDI & 0.93 & 0.61 & 1.03 & 8.42 \\
\hline Gil & 0.30 & 0.01 & 0.77 & 70.15 \\
\hline LPI & 57.21 & 0.74 & 79.85 & 19.76 \\
\hline E1 & 0.64 & 0.26 & 0.94 & 101.07 \\
\hline GDP & 17482.91 & 695.00 & 103388.00 & 21.78 \\
\hline HPI & 5.25 & 2.69 & 7.54 & 21.77 \\
\hline G1 & 38.68 & 24.10 & 63.40 & \\
\hline
\end{tabular}

Source: (National Accounts Main Aggregate Database, n/d)

The average level of Human Development Index made up 0.692, while its minimum value is 0.352 , maximum of 0.95. It is not enough high level. In the annual reports of the UN Development Programme (UNDP) high level is the value of the Human Development Index above 0.8. The average level of GDP at PPP per capita amounted to 17,483 dollars per year. But the high value of the variation coefficient does not allow considering this average value as representative and describing the totality as a whole. In the world there is a significant gender inequality among women and men: the average value of the Gender Inequality Index made up 0.302 , the variation coefficient in the indicator is high, more than $70 \%$, which indicates a strong difference of countries to each other (Gallup International, n/d; Income Gini coefficient, $\mathrm{n} / \mathrm{d}$ ). The 2018 Update presents HDI values for 189 countries and territories with the most recent data for 2017.1 Of these countries, 59 are in the very high human development group, 53 in the high, 39 in the medium and only 38 in the low. In 2010, 49 countries were in the low human development group. The top five countries in the global HDI ranking are Norway (0.953), Switzerland (0.944), Australia (0.939), Ireland (0.938) and Germany (0.936) (see statistical table 1). The bottom five are Burundi (0.417), Chad (0.404), South Sudan (0.388), the Central African Republic (0.367) and Niger (0.354). The largest increases in HDI rank between 2012 and 2017 were for Ireland, which moved up 13 places, and for Botswana, the Dominican Republic and Turkey, which each moved up 8. The largest declines were for the Syrian Arab Republic (down 27), Libya (26) and Yemen (20) (UNDP, 2018b).

By the Gini index, showing the income inequality among the population, in the whole set of countries is around $38 \%$. Thus, we can conclude that the problem of income inequality remains relevant to the global community. The average values of the Prosperity (57.2\%) and Happiness (5.25) Indexes demonstrate their low levels: economic and social issues remain unsolved for most countries. The average of the aggregate education index is equal to 0.642 , and its maximum value (0.94) exceeds the minimum (0.26) more in than 3.5 times.

Since the variation coefficients for some indicators exceed 33\%, indicating the heterogeneity of the population of studied economies than in the course of the study it was decided to conduct a cluster analysis on the basis of which you can break the set into homogeneous groups and further statistical research in the context of the obtained clusters (Akhmetshin et al., 2017). In the course of the dispersion analysis of the obtained clusters the calculated value level of significance allows us to accept the 
hypothesis of inequality of group dispersions (calculated significance levels much smaller than 0.05 adopted in the level study). Thus, such splitting of the countries into eight groups is reasonable (Table 3 ).

Table 3

The results of the variance analysis of clusters

\begin{tabular}{|c|c|c|c|c|c|c|}
\hline \multirow{2}{*}{ Variable } & \multicolumn{6}{|c|}{ Analysis of Variance } \\
\cline { 2 - 7 } & $\begin{array}{c}\text { Between } \\
\text { SS }\end{array}$ & df & $\begin{array}{c}\text { Within } \\
\text { SS }\end{array}$ & df & F & signif. $\mathbf{p}$ \\
\hline HDI & 121.2979 & 7 & 9.70211 & 124 & 221.4678 & 0.000000 \\
\hline HDII & 123.6396 & 7 & 7.36044 & 124 & 297.5618 & 0.000000 \\
\hline GDI & 80.0462 & 7 & 50.95383 & 124 & 27.8283 & 0.000000 \\
\hline Gil & 110.2483 & 7 & 20.75175 & 124 & 94.1111 & 0.000000 \\
\hline LPI & 94.7774 & 7 & 36.22260 & 124 & 46.3499 & 0.000000 \\
\hline E1 & 116.1890 & 7 & 14.81101 & 124 & 138.9645 & 0.000000 \\
\hline GDP & 113.8216 & 7 & 17.17838 & 124 & 117.3724 & 0.000000 \\
\hline HPI & 101.8697 & 7 & 29.13033 & 124 & 61.9474 & 0.000000 \\
\hline GI & 83.6171 & 7 & 47.38294 & 124 & 31.2605 & 0.000000 \\
\hline
\end{tabular}

Source: Compiled by the author

Graph of average values in the normalized view allows seeing the differences between the obtained clusters visually (see Fig. 1).

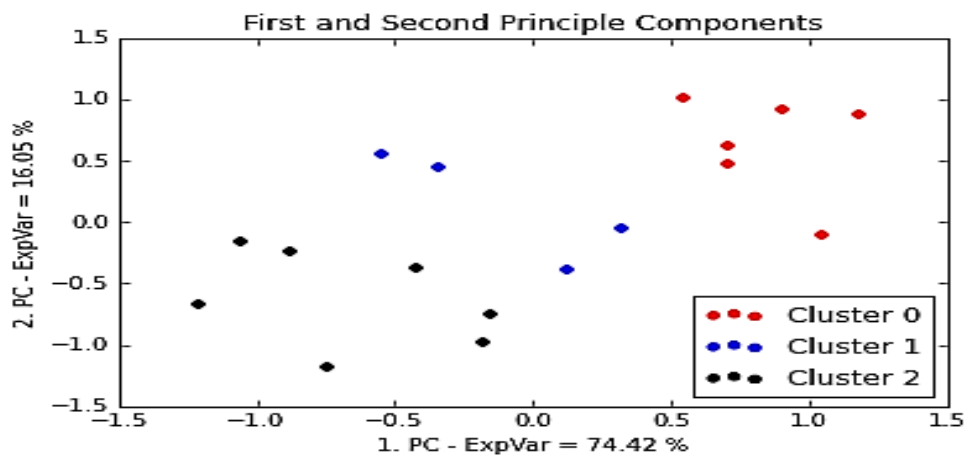

Figure 1. Graph of averages of clusters

Source: Compiled by the author

For ease of analysis, we range all averages of the clusters depending on the degree of decreasing values of this indicator (see Table. 4).

Table 4

Average values of clusters

\begin{tabular}{|c|c|c|c|c|c|c|c|c|}
\hline $\begin{array}{l}\text { Cluster } \\
\text { Indicator }\end{array}$ & $\begin{array}{c}1 \\
\text { "most } \\
\text { successful } \\
\text { countries" }\end{array}$ & $\begin{array}{c}2 \\
\text { "successful } \\
\text { countries" }\end{array}$ & \begin{tabular}{|c|}
3 \\
"wealthy \\
countries"
\end{tabular} & $\begin{array}{c}4 \\
\text { "promising } \\
\text { countries" }\end{array}$ & \begin{tabular}{|c|}
5 \\
"developing \\
countries"
\end{tabular} & \begin{tabular}{|c|}
\multicolumn{1}{|c|}{6} \\
"problematic \\
countries"
\end{tabular} & $\begin{array}{c}7 \\
\text { "disadvantaged } \\
\text { countries" }\end{array}$ & $\begin{array}{c}8 \\
\text { "the most } \\
\text { disadvantaged } \\
\text { countries" }\end{array}$ \\
\hline HDI & 0.92 & 0.86 & 0.76 & 0.75 & 0.73 & 0.63 & 0.57 & 0.46 \\
\hline HDII & 0.85 & 0.78 & 0.62 & 0.67 & 0.57 & 0.48 & 0.37 & 0.31 \\
\hline GDI & 0.98 & 0.99 & 0.98 & 0.97 & 0.91 & 0.92 & 0.92 & 0.83 \\
\hline GII & 0.08 & 0.13 & 0.37 & 0.24 & 0.43 & 0.11 & 0.41 & 0.59 \\
\hline LPI & 76.75 & 66.99 & 60.09 & 56.76 & 46.51 & 54.31 & 52.51 & 46.52 \\
\hline EL & 0.89 & 0.84 & 0.71 & 0.75 & 0.66 & 0.55 & 0.53 & 0.41 \\
\hline GDP & 55654 & 32485 & 17479 & 13257 & 15156 & 7155 & 5493 & 2792 \\
\hline HPI & 7.2 & 5.88 & 6.21 & 5.01 & 5.07 & 5.04 & 4.12 & 4.045 \\
\hline GI & 30.53 & 33.25 & 45.91 & 31.45 & 40.11 & 38.85 & 54.61 & 40.15 \\
\hline
\end{tabular}

Source: Compiled by the author 
Grades of average clusters indicators

\begin{tabular}{|c|c|c|c|c|c|c|c|c|}
\hline $\begin{array}{c}\text { Cluster } \\
\text { indicator }\end{array}$ & $\begin{array}{c}\mathbf{1} \\
\text { "the most } \\
\text { successful } \\
\text { countries" }\end{array}$ & $\begin{array}{c}\mathbf{2} \\
\text { "successful } \\
\text { countries" }\end{array}$ & $\begin{array}{c}\mathbf{3} \\
\text { "wealthy } \\
\text { countries" }\end{array}$ & $\begin{array}{c}\mathbf{4} \\
\text { "promising" }\end{array}$ & $\begin{array}{c}\mathbf{5} \\
\text { "developing" }\end{array}$ & $\begin{array}{c}\mathbf{6} \\
\text { "problematic" }\end{array}$ & $\begin{array}{c}\mathbf{7} \\
\text { "disadvantaged } \\
\text { countries" }\end{array}$ & $\begin{array}{c}\mathbf{8} \\
\text { "the most } \\
\text { disadvantaged } \\
\text { countries" }\end{array}$ \\
\hline HDI & 1 & 2 & 3 & 4 & 5 & 6 & 8 & 8 \\
\hline HDII & 1 & 2 & 4 & 3 & 5 & 6 & 8 & 8 \\
\hline GDI & 3 & 1 & 2 & 4 & 7 & 6 & 8 & 8 \\
\hline GII & 8 & 6 & 3 & 5 & 2 & 7 & 1 & 1 \\
\hline LPI & 1 & 2 & 3 & 4 & 8 & 5 & 7 & 7 \\
\hline EI & 1 & 2 & 4 & 3 & 5 & 6 & 8 & 8 \\
\hline GDP & 1 & 2 & 3 & 5 & 4 & 6 & 8 & 8 \\
\hline HPI & 1 & 3 & 2 & 6 & 4 & 5 & 8 & 8 \\
\hline GI & 8 & 6 & 2 & 7 & 4 & 5 & 3 & 3 \\
\hline
\end{tabular}

Source: Compiled by the author

Thus, the classification result has the following composition of the clusters.

The first cluster consists of socially advantaged and economically developed countries of the world. These "happy" countries in the analysis were eight: Norway, Australia, Switzerland, Germany, Denmark, Netherlands, Ireland, Iceland, Canada, USA, Sweden, UK, Luxembourg, Finland, Austria. It should be noted that Norway for a very long period of time, more than 10 years occupies the first place in terms of Human Development Index (National Accounts Main Aggregate Database, n/d.).

The statistical characteristics of this cluster allow us to call it the "most successful" countries of the world (Table 3). The highest Human Development Index, the highest levels of education and GDP allow the populations of these countries rightly consider them as "the countries best to live" (the highest indexes of prosperity and "happiness"). The lowest levels of property and gender inequality (see Table 4 and 5) resemble the equal social rights of men and women, and people with different cash incomes.

All indicators of the first cluster have variation coefficients lower than $33 \%$. This reflects the quality of homogeneity of the cluster and allows us to consider the results of further correlation and regression analyses adequate, corresponding to reality (Ranis et al., 2011).

Table 6

The matrix of linear coefficients of the cluster correlation No. 1

\begin{tabular}{|c|c|c|c|c|c|c|c|c|c|}
\hline \multirow[b]{2}{*}{ Variable } & \multicolumn{9}{|c|}{$\begin{array}{l}\text { Correlations ( } 1^{\text {st }} \text { cluster) } \\
\text { Marked correlations are sioni }\end{array}$} \\
\hline & HDI & HDII & GDI & Gil & LPI & E1 & GDP & HPI & G1 \\
\hline HDI & 1.00 & 0.68 & 0.10 & -0.06 & 0.35 & 0.80 & -0.02 & 0.36 & 0.10 \\
\hline HDII & 0.68 & 1.00 & 0.01 & -0.63 & 0.81 & 0.50 & -0.06 & 0.57 & -0.60 \\
\hline GDI & 0.10 & 0.01 & 1.00 & 0.20 & 0.22 & 0.04 & -0.03 & 0.25 & 0.07 \\
\hline Gil & -0.06 & -0.63 & 0.20 & 1.00 & -0.67 & 0.16 & -0.00 & -0.66 & 0.88 \\
\hline LPI & 0.35 & 0.81 & 0.22 & -0.67 & 1.00 & 0.16 & -0.11 & 0.56 & -0.68 \\
\hline E1 & 0.80 & 0.50 & 0.04 & 0.16 & 0.16 & 1.00 & -0.49 & 0.22 & 0.24 \\
\hline GDP & -0.02 & -0.06 & -0.03 & -0.00 & -0.11 & -0.49 & 1.00 & -0.19 & 0.03 \\
\hline HPI & 0.36 & 0.57 & 0.25 & -0.66 & 0.56 & 0.22 & -0.19 & 1.00 & -0.52 \\
\hline G1 & 0.10 & -0.60 & 0.07 & 0.88 & -0.68 & 0.24 & 0.03 & -0.52 & 1.00 \\
\hline
\end{tabular}

Source: Compiled by the author

The analysis of the matrix of linear correlation coefficients (see Table 6), shows that in the first cluster only the indication of education influences the Human Development Index (the correlation coefficient is high, equal to 0.8). Regression equation describing this dependence is presented in Table 7. 
Regression equations for the obtained clusters

\begin{tabular}{|c|c|c|}
\hline Cluster No & Regression equations & $\begin{array}{l}\text { The adjusted value of } \\
\text { the determination } \\
\text { coefficient, } \% * *\end{array}$ \\
\hline 1 & $\mathrm{HDI}=0.647878+0.306753 * \mathrm{El}$ & 60.9 \\
\hline 2 & $\begin{array}{c}\mathrm{HDI}=0.747326+0.000003 * \mathrm{GDP} \\
\mathrm{LPI}=52.5366+0.00044 * \mathrm{GDP} \\
\mathrm{HPI}=-0.999206+6.075056 * \mathrm{El}+0.000055^{*} \mathrm{GDP}\end{array}$ & $\begin{array}{l}24.2 \\
40.5 \\
44.8\end{array}$ \\
\hline 3 & $\mathrm{HDI}=0.494322+0.274726 * \mathrm{EL}+0.000004 * \mathrm{GDP}$ & 84.0 \\
\hline 4 & HDI $=0.491678+0.25808 * \mathrm{EL}+0.000001 * \mathrm{GDP}$ & 80.2 \\
\hline 5 & $\begin{array}{l}\text { The equations were not built in connection with the absence of significant } \\
\text { correlation coefficients }\end{array}$ & - \\
\hline 6 & HDI $=0.350889+0.434271 * \mathrm{EL}+0.000006 * \mathrm{GDP}$ & 79.0 \\
\hline 7 & $\begin{array}{c}\mathrm{HDI}=0.557167-0.145608^{*} \mathrm{GII}+0.000011 * \mathrm{GDP} \\
\mathrm{El}=0.45677+0.000003 * \mathrm{GDP} \\
\mathrm{GDP}=-32418.5+694.6^{*} \mathrm{Gl}\end{array}$ & $\begin{array}{l}85.1 \\
68.9 \\
40.8 \\
\end{array}$ \\
\hline 8 & $\mathrm{HDI}=0.33154+0.255923 * \mathrm{E} 1+0.000011 * \mathrm{GDP}$ & 24.5 \\
\hline
\end{tabular}

* all regression equations and regression coefficients are significant at a significance level less than 0.05 . Regression coefficients are also significant at a level less than 0.05 by t-test.

** adjusted determination coefficient considers the number of variables included in the model (its value is less than the value of the determination coefficient). The coefficient of determination is also significant at a level less than 0.05 according to the Fisher criterion. All regression models' characteristics (testing) are given in the Appendix of the article.

Source: Compiled by the author

GDP per capita turned out to be unrelated to any of the indicators involved in the analysis, as it could be expected on the basis of the above. Gender-related Development Index in this group of countries has a negative impact on the Prosperity Index and the Happiness Index (the average degree of linkage, if to estimate according to the generally accepted scale of Cheddar). A high degree of linkage the Gender-related Development Index has only with the Gini Index (0.88).

The Gini Index, in turn, negatively affects the Prosperity and Happiness Index (average degree of linkage), but virtually doesn't affect GDP and Education Index, which is natural for developed countries (Ostry et al., 2014). Thus, for countries with a high level of economic development, the Human Development Index is no longer been influenced by economic factors, social issues become prominent.

The second cluster consists of countries such as Japan, Israel and some countries of Europe (17 countries): France, Slovenia, Italy, Spain, Czech Republic, Greece, Estonia, Cyprus, Poland, Lithuania, Slovakia, Portugal, Hungary, Latvia, Croatia. As we can see, these countries are quite developed, with high values of Human Development Index, Education, Prosperity (the indexes take the 2nd place in the aggregate); the high enough Happiness Index (3rd place). The country's Gender-related Development Index ranks first in the world, its value approaches a limit - the unit has low levels of property and gender inequality. All of the above allows us to characterize this group of countries as "successful."

Average values of clusters are relatively high (see Table 7), except for the Gender Inequality Index and the Gini coefficient, a low value which, on the contrary, say the positive trends in development. The cluster is homogeneous, the correlation coefficients for all indicators are below 33\%. GDP per capita is high. In comparison with the third cluster, it is bigger almost 2 times, compared to the most disadvantaged cluster, the eighth, its value is superior to almost 12 times.

Analysis of the matrix of pairwise (linear) correlation coefficients allows drawing the following conclusions (see Table 8). 
The matrix of linear coefficients of the cluster correlation No. 2

\begin{tabular}{|c|c|c|c|c|c|c|c|c|c|}
\hline \multirow[b]{2}{*}{ Variable } & \multicolumn{9}{|c|}{$\begin{array}{l}\text { Correlations }\left(2^{\text {nd }} \text { cluster) }\right. \\
\text { Marked correlations are significant at } p<, 05000 \\
N=17 \text { (Casewise deletion of missing data) }\end{array}$} \\
\hline & HDI & HDII & GDI & Gil & LPI & E1 & GDP & HPI & G1 \\
\hline HDI & 1.00 & 0.54 & -0.17 & -0.40 & 0.61 & 0.08 & 0.54 & -0.14 & -0.41 \\
\hline HDII & 0.54 & 1.00 & -0.13 & -0.36 & 0.66 & 0.51 & 0.58 & 0.47 & -0.56 \\
\hline GDI & -0.17 & -0.13 & 1.00 & 0.27 & -0.03 & 0.43 & -0.36 & -0.09 & 0.06 \\
\hline Gil & -0.40 & -0.36 & 0.27 & 1.00 & -0.59 & -0.03 & -0.47 & -0.20 & -0.10 \\
\hline LP 1 & 0.61 & 0.66 & -0.03 & -0.59 & 1.00 & 0.09 & 0.66 & 0.28 & -0.30 \\
\hline E1 & 0.08 & 0.51 & 0.43 & -0.03 & 0.09 & 1.00 & 0.16 & 0.50 & -0.16 \\
\hline GDP & 0.54 & 0.58 & -0.36 & -0.47 & 0.66 & 0.16 & 1.00 & 0.59 & -0.22 \\
\hline HPI & -0.14 & 0.47 & -0.09 & -0.20 & 0.28 & 0.50 & 0.59 & 1.00 & 0.01 \\
\hline G1 & -0.41 & -0.56 & 0.06 & -0.10 & 0.30 & -0.16 & -0.22 & 0.01 & 1.00 \\
\hline
\end{tabular}

Source: Compiled by the author

The Gender Inequality Index affects the value of the Prosperity Index, that was to be expected. That is, the unequal social opportunities are changing people's opinions about the country as "the best for living". In general, there is a slightly unusual situation at the cluster: all indicators are not much interlinked. If there is a linkage, it is low (correlation coefficients for the module are not higher than 0.66). The incompatibility of indicators among themselves raises the issue of the reliability of the information that is the basis of the considered indexes. The following fact can serve as the confirmation: the Education Index has no connection with the Human Development Index (correlation coefficient is equal to 0.08), in contrast to the first cluster, in which the change of values of this index is almost entirely determined by the Education Index.

Table 7 presents the regression equation describing the dependence of the indexes of Human Development, Prosperity and "Happiness" from significant indicators. As for the third cluster it consists of 16 countries, mainly from Latin America: Chile, Argentina, Russia, Uruguay, Panama, Fiji, Costa Rica, Venezuela, Mexico, Brazil, Peru, Thailand, Ecuador, Colombia, Belize, Paraguay. This group is characterized by a rather high level of human potential (the third place in the aggregate), the average GDP per capita (the third place), a high Happiness Index (the second), indicating a fairly prosperous socioeconomic situation of the countries (see Table 4 and 5). The intermediate position this cluster takes by the level of education (the fourth place). All this allows naming the countries of this cluster "wealth" for human development. However, there are some negative points. Thus, the Gini Index indicates strong stratification among the population (the second place). Although the obtained correlation coefficients show that the wealth stratification has almost no effect on socio-economic indicators (see Table 9), because the correlation coefficients are insignificant, as the global economic practice, reducing the Gini coefficient always has certain advantages in the development of human capacities. Also, in this cluster, there is a fairly noticeable gender inequality among men and women, which unlike the Gini Index, which is already beginning to have a significant impact on human potential, level of education, even on GDP. 
The matrix of linear coefficients of the cluster correlation No. 3

\begin{tabular}{|c|c|c|c|c|c|c|c|c|c|}
\hline \multirow{2}{*}{ Variable } & \multicolumn{9}{|l|}{$\begin{array}{l}\text { Correlations (3rd cluster) } \\
\text { Marked correlations are significant at } \mathbf{p}<\mathbf{0 5 0 0 0} \\
\text { N=16 (Casewise deletion of missing data) }\end{array}$} \\
\cline { 2 - 12 } & HDI & HDII & GDI & G1 I & LPI & E1 & GDP & HPI & G1 \\
\hline HDI & 1.00 & 0.90 & 0.16 & -0.50 & 0.35 & 0.82 & 0.88 & 0.43 & -0.06 \\
\hline HDII & 0.90 & 1.00 & 0.17 & -0.62 & 0.27 & 0.89 & 0.85 & 0.18 & -0.36 \\
\hline GDI & 0.16 & 0.17 & 1.00 & 0.02 & -0.29 & 0.16 & 0.23 & -0.05 & -0.00 \\
\hline G1 I & -0.50 & -0.62 & 0.02 & 1.00 & -0.32 & -0.51 & -0.50 & -0.48 & 0.40 \\
\hline LPI & 0.35 & 0.27 & -0.29 & -0.32 & 1.00 & 0.12 & 0.38 & 0.54 & 0.01 \\
\hline E1 & 0.82 & 0.89 & 0.16 & -0.51 & 0.12 & 1.00 & 0.69 & 0.11 & -0.33 \\
\hline GDP & 0.88 & 0.85 & 0.23 & -0.50 & 0.38 & 0.69 & 1.00 & 0.39 & -0.14 \\
\hline HPI & 0.43 & 0.18 & -0.05 & -0.48 & 0.54 & 0.11 & 0.39 & 1.00 & 0.21 \\
\hline G1 & -0.06 & -0.36 & -0.00 & 0.40 & 0.01 & -0.33 & -0.14 & 0.21 & 1.00 \\
\hline
\end{tabular}

Source: Compiled by the author

As for the index of education then depending on the matrix of linear correlation coefficients, it has close linkage with GDP. Thus, we can say that with the strengthening of the economic situation, the situation in education and the human potential begins to improve significantly. The decrease in the level of gender inequality also allows raising the indexes of education and human development. The regression equation describing the dependence of the human potential on total GDP and education level are presented in Table 5.

The fourth cluster consists of the former socialist countries, mainly former Soviet republics and countries of Europe (16 countries): Montenegro, Romania, Belarus, Bulgaria, Serbia, Georgia, Sri Lanka, Albania, Azerbaijan, Bosnia and Herzegovina, Macedonia, Armenia, Ukraine, Mongolia, Moldova, Kyrgyzstan.

According to its characteristics, this cluster can be attributed to "promising countries" (see Table. 1 and 4). Low level of income inequality and low gender difference among the population, the average indicators of the indexes of human development (fourth place according to the set of countries) and education (third place), - all this allows us to assign countries to the category of "promising." According to the Human Development Index takes into account the Gender Inequality Index and Gender-related Development Index, this cluster has the third place after the developed countries of the world. Average values can be seen in Table 4. The cluster is homogeneous, the variation coefficients on all indicators, except for GDP, does not exceed $10 \%$, GDP is $33 \%$, which demonstrates the high quality of clustering.

The matrix of linear correlation coefficients also allows you to name this group of countries as "promising". Correlations reflect the positive development of the indicators from the point of view of economic and social progress. Here the Human Development Index depends primarily on the size of the GDP and Index Education (see Table 10). Regression equation describing this dependence is presented in Table 5. 
The matrix of linear coefficients of the cluster correlation No. 4

\begin{tabular}{|c|c|c|c|c|c|c|c|c|c|}
\hline \multirow[b]{2}{*}{ Variable } & \multicolumn{9}{|c|}{$\begin{array}{l}\text { Correlations ( } 4^{\text {th }} \text { cluster) } \\
\text { Marked correlations are significant at } p<, 05000 \\
N=16 \text { (Casewise deletion of missing data) }\end{array}$} \\
\hline & HDI & HDII & GDI & G1 I & LPI & E1 & GDP & HPI & G1 \\
\hline HDI & 1.00 & 0.89 & -0.08 & 0.29 & 0.64 & 0.53 & 0.86 & 0.08 & 0.26 \\
\hline HDII & 0.89 & 1.00 & 0.19 & 0.21 & 0.41 & 0.79 & 0.69 & 0.06 & -0.03 \\
\hline GDI & -0.08 & 0.19 & 1.00 & 0.01 & -0.00 & 0.46 & -0.06 & 0.13 & -0.50 \\
\hline Gil & 0.29 & 0.21 & 0.01 & 1.00 & 0.34 & 0.14 & 0.16 & -0.38 & 0.34 \\
\hline LPI & 0.64 & 0.41 & -0.00 & 0.34 & 1.00 & 0.13 & 0.64 & 0.12 & 0.42 \\
\hline E1 & 0.53 & 0.79 & 0.46 & 0.14 & 0.13 & 1.00 & 0.30 & 0.10 & -0.16 \\
\hline GDP & 0.86 & 0.69 & -0.06 & 0.16 & 0.64 & 0.30 & 1.00 & 0.34 & 0.18 \\
\hline HPI & 0.08 & 0.06 & 0.13 & 0.38 & 0.12 & 0.10 & 0.34 & 1.00 & 0.36 \\
\hline G1 & 0.26 & -0.03 & -0.50 & 0.34 & 0.42 & -0.16 & 0.18 & -0.36 & 1.00 \\
\hline
\end{tabular}

Source: Compiled by the author

The Gender Inequality Index and the Gini Index in this cluster do not have any influence on other parameters because of their small values.

The fifth cluster, "developing countries" includes Iran, Turkey, Algeria, Jordan, Tunisia, Dominican Republic, Uzbekistan, Gabon, Egypt (9 countries).

The residents themselves assess their country as unfavourable for a living, the cluster has the lowest level of the Prosperity Index, it is clearly extremely subjective as there are countries in the world much worse for living according to their socio-economic characteristics (e.g., countries of 7 and 8 clusters, see above). Human Development Indexes, education, and GDP are somewhat lower than average world levels (see Table 4 and 5). This cluster is characterized by a high degree of gender inequality, as well as a strong stratification of the population on property inequality (high Gini Index).

As it can be seen from the matrix of linear correlation coefficients (see Table 11), property inequality among the population has a negative impact on education and human development level (the correlation coefficients of the Gini index with the indexes of Human Development and education has negative values). Interestingly, at this group of countries, almost all indicators with some exceptions, are not linked. The simplest and the most realistic explanation for this: information on indicators and indexes involved in the analysis is highly distorted and untrue. In this regard, according to this cluster in the study, regression models were not built.

Table 11

The matrix of linear coefficients of the cluster correlation No. 5

\begin{tabular}{|c|c|c|c|c|c|c|c|c|c|}
\hline \multirow[b]{2}{*}{ Variable } & \multicolumn{9}{|c|}{$\begin{array}{l}\text { Correlations }\left(5^{\text {th }} \text { claster) }\right. \\
\text { Marked correlations are significant at } \mathrm{p}<.05000 \\
\mathrm{~N}=9 \text { (Casewise deletion of missing data) }\end{array}$} \\
\hline & HDI & HDII & GDI & Gil & LPI & E1 & GDP & HPI & G1 \\
\hline HDI & 1.00 & 0.45 & -0.44 & -0.16 & 0.42 & 0.40 & 0.50 & 0.20 & -0.38 \\
\hline HDII & 0.45 & $1 . \mathrm{OO}$ & -0.02 & -0.61 & -0.04 & 0.45 & 0.04 & 0.69 & -0.17 \\
\hline GDI & -0.44 & -0.02 & 1.00 & -0.23 & -0.37 & -0.18 & -0.07 & -0.31 & 0.68 \\
\hline Gil & -0.16 & -0.61 & 0.23 & 1.00 & 0.40 & -0.47 & 0.33 & -0.57 & 0.44 \\
\hline LPI & 0.42 & -0.04 & -0.37 & 0.40 & 1.00 & -0.57 & 0.65 & -0.48 & 0.05 \\
\hline E1 & 0.40 & 0.45 & -0.18 & -0.47 & -0.57 & 1.00 & -0.36 & 0.65 & -0.53 \\
\hline GDP & 0.50 & 0.04 & -0.07 & 0.33 & 0.65 & -0.36 & 1.00 & -0.38 & 0.25 \\
\hline HPI & 0.20 & 0.69 & -0.31 & -0.57 & -0.48 & 0.65 & -0.38 & 1.00 & -0.48 \\
\hline G1 & -0.38 & -0.17 & 0.68 & 0.44 & 0.05 & -0.53 & 0.25 & -0.48 & 1.00 \\
\hline
\end{tabular}

Source: Compiled by the author 
The sixth cluster is quite large, consisting of 21 countries, mainly from Asia and Latin America. It includes China, Indonesia, Vietnam, Philippines, El Salvador, Bolivia, Iraq, Morocco, Nicaragua, Guatemala, Guyana, Tajikistan, Honduras, India, Bhutan, Laos, Bangladesh, Ghana, Sao Tome and Principe, Cambodia, Nepal.

The sixth cluster countries are "problematic countries". They have a low GDP, low Human Development and Education Indexes (see Table 4 and 5). The group is characterized by a low level of gender inequality that is a positive development. However, the high variation coefficient for this indicator $(71 \%)$ means that cluster objects are highly heterogeneous in terms of gender inequality, they are under completely different policies in terms of equal social rights of men and women. In the group, there is a small income inequality among the population (low value of the Gini Index), which is also a positive feature of the cluster.

The matrix of pairwise (linear) correlation coefficients allows making a conclusion about the strong dependence of the Human Development Index on the level of education and GDP per capita (see Table 12). Regression linkage between them is presented in Table 7. The matrix of a linear (pairwise) correlation coefficients has the form (Table 12):

Table 12

The matrix of linear coefficients of the cluster correlation No. 6

\begin{tabular}{|c|c|c|c|c|c|c|c|c|c|}
\hline \multirow[b]{2}{*}{ Variable } & \multicolumn{9}{|c|}{$\begin{array}{l}\text { Correlations }\left(6^{\text {th }} \text { cluster) }\right. \\
\text { Marked correlations are significant at } \mathrm{p}<, 05000 \\
\mathrm{~N}=21 \text { (Casewise deletion of missing data) }\end{array}$} \\
\hline & \begin{tabular}{|l|} 
HDI \\
\end{tabular} & HDII & GDI & G11 & LPI & E1 & GDP & HPI & GI \\
\hline HDI & 1.00 & 0.87 & 0.32 & 0.49 & 0.34 & 0.75 & 0.67 & 0.55 & 0.44 \\
\hline HDII & 0.87 & 1.00 & 0.40 & -0.55 & 0.28 & 0.79 & 0.58 & 0.33 & 0.07 \\
\hline GDI & 0.32 & 0.40 & 1.00 & -0.37 & 0.54 & 0.46 & -0.24 & 0.49 & 0.39 \\
\hline Gil & -0.49 & -0.55 & -0.37 & 1.00 & -0.33 & -0.48 & -0.18 & -0.49 & -0.26 \\
\hline LPI & 0.34 & 0.28 & 0.54 & -0.33 & 1.00 & 0.46 & -0.18 & 0.45 & 0.52 \\
\hline E1 & 0.75 & 0.79 & 0.46 & -0.48 & 0.46 & 1.00 & 0.24 & 0.33 & 0.28 \\
\hline GDP & 0.67 & 0.58 & -0.24 & -0.18 & -0.18 & 0.24 & 1.00 & 0.04 & 0.02 \\
\hline HPI & 0.55 & 0.33 & 0.49 & -0.49 & 0.45 & 0.33 & 0.04 & 1.00 & 0.72 \\
\hline G1 & 0.44 & 0.07 & 0.39 & -0.26 & 0.52 & 0.28 & 0.02 & 0.72 & 1.00 \\
\hline
\end{tabular}

Source: Compiled by the author

The dependence of the Education Index on total GDP in this cluster is irrelevant. Mostly the Education Index is associated with a particular country of residence (obviously, there is a difference between the politicians of these countries in relation to education) and Human Development Index.

Gender inequality in this group of countries is small and, as expected, has a negative impact on other socio-economic indicators involved in the analysis.

If you look at the matrix of linear correlation coefficients, you can see that the Gini Index in spite of its economic sense, has a positive effect on the Human Development Index and the Happiness Index. This can be explained by two reasons: information on the Gini coefficient is not entirely correct (i.e. you must additionally check the information on this indicator), or the average degree of income inequality, contrary to popular opinion, has a positive effect on some aspects of socio-economic development of society at a certain group of countries.

The seventh cluster "disadvantaged countries" has included a number of African countries and Haiti (9 countries): Botswana, South Africa, Namibia, Republic of Congo, Zambia, Kenya, Rwanda, Lesotho, Haiti. If you look at the graph of the average values of the clusters (see Fig. 1) and the table of ranks of averages of clusters indicators (see Table 5), it is evident that this group of countries has the largest stratification of income inequality (highest Gini coefficient), but the low gender inequality, i.e. social 
opportunities of men and women in this group are not as high as in other countries (grade 4). Low values of the indexes of education, prosperity, happiness characterize this group of countries, as quite unfavourable for a living. In fairness, it should be said that the most disadvantaged group of countries in the analysis were the eighth cluster countries.

The matrix of pairwise (linear) correlation coefficients of the seventh cluster has the form (see Table 13):

Table 13

The matrix of linear coefficients of the cluster correlation No. 7

\begin{tabular}{|c|c|c|c|c|c|c|c|c|c|}
\hline \multirow{3}{*}{ Variable } & \multicolumn{9}{|l|}{$\begin{array}{l}\text { Correlations (7th claster) } \\
\text { Marked correlations are significant } \\
\text { N=9 (Casewise deletion of missing at p < , 05000 data) }\end{array}$} \\
\cline { 2 - 11 } & HDI & HDII & GDI & GM I & LPI & El & GDP & HPI & Gl \\
\hline HDI & 1.00 & 0.90 & 0.71 & -0.68 & 0.40 & 0.78 & 0.88 & 0.34 & 0.55 \\
\hline HDII & 0.90 & 1.00 & 0.71 & -0.74 & 0.15 & 0.61 & 0.65 & 0.47 & 0.18 \\
\hline GDI & 0.71 & 0.71 & 1.00 & -0.63 & 0.61 & 0.38 & 0.59 & -0.00 & 0.19 \\
\hline Gil & -0.68 & -0.74 & -0.63 & 1.00 & 0.06 & 0.52 & -0.43 & -0.48 & 0.35 \\
\hline LPI & 0.40 & 0.15 & 0.61 & 0.06 & 1.00 & 0.20 & 0.50 & -0.40 & 0.33 \\
\hline El & 0.78 & 0.61 & 0.38 & -0.52 & 0.20 & 1.00 & 0.85 & 0.57 & 0.57 \\
\hline GDP & 0.88 & 0.65 & 0.59 & -0.43 & 0.50 & 0.85 & 1.00 & 0.14 & 0.69 \\
\hline HRI & 0.34 & 0.47 & -0.00 & -0.48 & -0.40 & 0.57 & 0.14 & 1.00 & -0.02 \\
\hline GI & 0.55 & 0.18 & 0.19 & -0.35 & 0.33 & 0.57 & 0.69 & -0.02 & 1.00 \\
\hline
\end{tabular}

Source: Compiled by the author

In this cluster, the Human Development Index is affected by the gender inequality, GDP and Education Index. And the greatest influence has been made not by the Education Index, but by the GDP per capita, which is natural for countries with low level of socio-economic development. Obviously, the primary in this group is meeting the physical needs of people, allowing to elementary survive. Gender inequality significantly reduces the amount of human potential that must not be indifferent to the governments of those States, if they want prosperity and welfare for their countries. In the form of the regression model, the dependence between the Human Development Index and these indicators can be seen in Table 7.

Interestingly, in this cluster, the Education Index is directly related to the level of GDP (correlation coefficient 0.85 ), i.e. the welfare of the population allows to raise the level of education, the regression model of dependence, see table).

The unusual relationship in this cluster emerged between GDP and Gini Index. If in the totality of countries, the link between them is inverse and insignificant (correlation coefficient is equal to $-0.4 \mathrm{~V}$ ), in this case, on the contrary: the linkage between indicators is positive and quite high (0.69). That is, the increase in income inequality, in this case, leads to an increase in GDP per capita. This suggests that countries of this group are developing absolutely in a different way than most countries in the world, by some other economic laws that are different not only from European countries but in general, different from all other countries in the world.

Interestingly, such indicators as the index of prosperity and happiness, have no significant linkage with any of the indicators involved in the analysis. Obviously, for this group of countries, the methodology of these indexes is out of date, they do not have any analytical meaning.

The biggest was the eighth cluster of 29 countries consisting of mainly African countries and some Asian countries: Pakistan, Angola, Tanzania, Nigeria, Cameroon, Zimbabwe, Mauritania, Madagascar, Senegal, Uganda, Sudan, Togo, Benin, Yemen, Afghanistan, Malawi, Cote d'Ivoire, Ethiopia, Mali, Democratic Republic of the Congo, Liberia, Guinea-Bissau, Sierra Leone, Mozambique, Burundi, Burkina 
Faso, Chad, Nigeria, Central African Republic. This is the cluster with the lowest indicators of socioeconomic development (see Table), with the highest level of gender inequality and a moderate degree of stratification (it would be better to say that there is no rich in this cluster, all are poor). This group of countries in the study is called "the most disadvantaged countries" of the world.

The average size of GDP at PPP per capita in this cluster is almost 20 times less than the first such indicator, the most prosperous of the cluster. The numbers are horrifying, it should make think the world community and world humanitarian organizations. The value of the Human Development Index is more than 2 times less than the same indicator of the first cluster. A high degree of gender inequality (the value of Gender Inequality Index made up 0.598; in the first cluster, the indicator is 0.08 ), the low level of education (compared to the first cluster it is lower more than in 2 times) characterize these countries as in need of economic assistance.

The attention should be paid to the fact that the matrix of linear correlation coefficients (see Table 14) of the linkage between the indicators is insignificant (with the exception of Human Development Index and human development index adjusted for inequality; the linkage between indexes is almost functional that results from the methodology of their calculation). Obviously, the information on the studied indicators is not entirely representative, which is not surprising, given the adverse situation in these countries, which, undoubtedly, affects the quality of collecting statistical information.

Table 14

The matrix of linear correlation coefficients of the 8 cluster indicators

\begin{tabular}{|c|c|c|c|c|c|c|c|c|c|}
\hline \multirow{2}{*}{$\begin{array}{l}\text { Correlations (8 } \\
\text { Marked correlations are significant at } \mathbf{p}<\mathbf{0 5 0 0 0} \\
\text { Variable }\end{array}$} & N=29 (Casewise deletion of missing data) \\
\hline & HDI & HDII & GDI & GM & LPI & El & GDP & HPI & Gl \\
\hline HDI & 1.00 & 0.91 & 0.11 & -0.47 & 0.17 & 0.43 & 0.42 & 0.21 & 0.04 \\
\hline HDII & 0.91 & 1.00 & 0.24 & -0.49 & 0.32 & 0.50 & 0.29 & 0.21 & -0.01 \\
\hline GDI & 0.11 & 0.24 & 1.00 & -0.41 & 0.65 & 0.18 & -0.40 & -0.07 & 0.04 \\
\hline Gil & -0.47 & -0.49 & -0.41 & 1.00 & -0.34 & -0.31 & -0.18 & -0.06 & 0.06 \\
\hline LRI & 0.17 & 0.32 & 0.65 & -0.34 & 1.00 & 0.35 & 0.14 & 0.27 & 0.26 \\
\hline El & 0.43 & 0.50 & 0.18 & -0.31 & 0.35 & 1.00 & 0.21 & 0.08 & 0.51 \\
\hline GDP & 0.42 & 0.29 & -0.40 & -0.18 & 0.14 & 0.21 & 1.00 & 0.54 & 0.05 \\
\hline HPI & 0.21 & 0.21 & -0.07 & -0.06 & 0.27 & 0.08 & 0.54 & 1.00 & 0.01 \\
\hline G1 & 0.04 & -0.01 & 0.04 & 0.06 & 0.26 & 0.51 & 0.05 & -0.01 & 1.00 \\
\hline
\end{tabular}

Source: Compiled by the author

The equation of dependence of the Human Development Index on the GDP and the Education Index is presented in Table 5 .

\section{DISCUSSION}

In the course of the study, the objective was to determine how indexes of prosperity, happiness and human development are coordinated among themselves. To implement this is possible if to follow the logical linkage of these indicators. For example, if the indexes have no interlinkage and no linkage with the other indicators present in the analysis, it is possible to raise the question about the quality of the information or methodology that is the basis of their calculation. Another example is the presence of feedback between indicators, which according to the logic of their construction have a direct link, that also raises questions about the adequacy of the calculated indexes. 


\section{CONCLUSION}

Thus, following logical linkage and matching them with ties that were detected during the research, the following conclusions were made.

Fully accurate can be considered the information to build indexes of human development, prosperity and "happiness" only for the countries included in the first, second and sixth clusters; the methodology of calculation of these indexes adequately reflects the processes.

The third, fifth and seventh clusters require a revision of the methodology of calculation of indexes of prosperity and "happiness" in terms of comparability (over different countries) of indicators, their underlying (in the third cluster indexes are linked to each other, that is illogical; also, indexes have feedback in the seventh and the fifth cluster, which contradicts the methodologies of their construction).

In the fourth cluster the unreliability of Happiness Index causes concern (it has no connection with any of the indicators, which violates the socio-economic rules of interrelations of indicators).

In the eighth cluster, the Prosperity Indexes are calculated incorrectly (completely broken logical links with other indicators, for example, here the Prosperity Indexes are increasing with decreasing level of GDP per capita and an increase in income inequality among the population, which is at least absurd).

Also due to the results of the conducted research, we can draw the following conclusions about the priority directions of human potential evolution in countries with different existing socio-economic levels and their specific conditions for its development.

For the countries of the first cluster, which is the research were called the "most successful" countries in the world, the value of the Human Development Index is mainly influenced by social factors. Obviously, when reaching a certain economic level, the state starts to affect its human potential already with the social positions, in particular, enhancing the quality and level of education.

For the governments of second cluster countries ("successful" countries), it would be desirable to pay attention to the situation of gender inequality, to provide the required stable growth of the Human Development Index. Also, the particular dilemma requires discussion: why changes in the level of education did not affect the human potential of these countries.

Countries of the third group ("wealth" countries) demonstrated the high potential of the achievements in the economic, social spheres, and also in terms of human development. However, to implement them, the activities of States should be directed to solving problems strong stratification of society by income and gender inequality.

For States of the fourth group of "promising countries", consisting of former socialist countries of Europe and republics of the USSR, the Human Development Index will grow with increasing GDP per capita. The latter also has a strong influence on the level of education. Thus, the overall economic situation must inevitably lead to the progress of the human potential of these countries.

The decision of problems of the human potential of the countries of the fifth cluster (a group of "developing" countries) is closely associated with high gender and income inequality among the population.

For the sixth group of "problematic countries", the largest, consisting of China, Asia and Latin America, the primary goal is improving the overall economic welfare of the population, which should lead to higher indexes of education and human development.

"Disadvantaged countries" of the seventh group, consisting of African countries and Haiti, have big problems in the whole socio-economic sphere. But for the governments of the countries, it could be advisable to give priority to solving the problems of income inequality among the population, which hinders the economic development of these countries and reduces the human potential of the state. 
The most disadvantaged countries in the world, included in the eighth group have the lowest values of socio-economic indicators and the lowest human potential on the planet. It is obvious that these countries are no longer able to cope with the socio-economic problems, they need specific economic and humanitarian assistance to that part of the world community, which is not far from the concept of humanism.

\section{REFERENCES}

Akhmetshin, E. M., Barmuta, K. A., Yakovenko, Z. M., Zadorozhnaya, L. I., Mironov, D. S., \& Klochko, E. N. (2017). Advantages of cluster approach in managing the economy of the Russian Federation. International Journal of Applied Business and Economic Research, 15(23), 355-364.

Barro, R., \& Xavier, S.-i.-M. (2012).Convergence. Journal of Political Economy, 100(2), 223-251. doi:10.1086/261816

Benjamin, M. F. (2016). A Century of Growthand Improvement. American Economic Review, 106(5), 52-56. doi: $10.1257 /$ aer.p20161069

Berg, A. G., \& Ostry, J. D. (2011). Inequality and Unsustainable Growth: Two Sides of the Same Coin? IMF Staff Discussion Note, April 8, 50-55. Retrieved https://www.imf.org/external/pubs/ft/sdn/2011/sdn1108.pdf

Clark, A. E., \& Senik, C. (2016). Will GDP Growth Increase happiness in developing countries?. Discussion paper series Forschungsinstitutzur Zukunftder Arbeit, No. 5595, Bonn: Institute for the Study of Labor (IZA). Retrieved from: http://nbn-resolving.de/urn:nbn:de:101:1-201104134176

Easterly, W. (1999). Life During Growth. Journal of Economic Growth, 4(3), 239-275.

Education index. (n/d). Retrieved from: http://hdr.undp.org/en/content/education-index (accessedon May 5 2019).

Desai, R. M. \& Rudra, N. (2018). Trade, poverty, and social protection in developing countries. European Journal of Political Economy. Retrieved from: https://doi.org/10.1016/j.ejpoleco.2018.08.008

Gallup International official website. (n/d). Retrieved from: http://www.gallup-international.com/ (accessed on May 20 2019)

Gender Development Index (GDI). (n/d). Retrieved from: http://hdr.undp.org/en/content/gender-development-indexgdi (accessed on April 14 2019)

Gender Inequality Index (GII). (n/d).Retrieved from: http://hdr.undp.org/en/content/gender-inequality-index-gii (accessed on March 11 2019).

Grimm, M., Harttgen, K., Klasen, S., Misselhorn, M., Munzi, T., \& Smeeding, T. (2010). Inequality in Human Development: An EmpiricalAssessment of 32 countries. Social Indicators Research: An International and Interdisciplinary Journal for Quality-of-Life Measurement, 97(2),191-211. doi: https://doi.org/10.1007/s11205-0099497-7

Hanushek, E. A. (2013). Economic growth in developing countries: The role of human capital. Economic of Education Review, 37, 204-212. doi: https://doi.org/10.1016/j.econedurev.2013.04.005

Happy Planet Index. (2016). Retrieved from: http://happyplanetindex.org/countries/ (accessed on April 5 2019).

Income Gini coefficient. (n/d). Retrievedfrom: http://hdr.undp.org/en/content/income-gini-coefficient (accessed on March 1 2019)

Jones, Ch. I., \& Klenow, P. J. (2016). Beyond GDP? Welfare across countries and time. American Economic Review, 106(9), 2426-2457. doi: 10.1257/aer.20110236

Lind, J. Th.,\&Moene, K. O. (2009). Miserly Developments. Univ. Of Oslo, Dept. Of Economics Memorandum No. 04/2009 (January 28). doi: http://dx.doi.org/10.2139/ssrn.1361464

National Accouns Main Aggregate Database. (n/d). Retrieve from: https://unstats.un.org/UNSD/snaama/dnllist.asp (accessed on April 23 2019).

Ostry, J. D., Berg, A., \& Tsangarides, Ch. G. (2014). Redistribution, Inequality, andGrowth. International Monetary Fund Staff Discussion Note.pp. 120-125. Retrieved from: https://www.imf.org/external/pubs/ft/sdn/2014/sdn1402.pdf

Pritchett, L. (2013). The Rebirth of Education, Schooling ain't Learning. Washington, D.C.: Centerfor Global Development. pp. 62-65 
Ranis, G., Suri, T., \& Frances, S. (2011). Pathto Success: The relationship between Human Development and Economic Growth. World Development, Elsevier, 39(4), 506-522.

Stock, J. H. \& Watson, M. W. (2014). Introduction to Econometrics. $3^{\text {rd }}$ ed. New York: Pearson Series in Economics

The Legatum Prosperty Index. (2017). Retrieved from: https://www.prosperity.com

UNSD Solutions Network (2019). World Happiness Report 2019. Retrived from: https://worldhappiness.report/ed/2019/

UNDP. (2018a). Human Development Index. Retrieved from: http://hdr.undp.org/en/content/human-developmentindex-hdi (accessed on April 29 2019).

UNDP. (2018b). Human Development Indices and Indicators. Statistical Update. http://hdr.undp.org/sites/default/files/2018_human_development_statistical_update.pdf

Unleash. (2019). Unleash Program. https://unleash.org/

Weil, D. N. (2013). Economic Growth. 3rd ed. London: Pearson Education Limited.

Weisbrot, M., \& Ray, R. (2010). The Scorecardon Development, 1960-2010: Closing the Gap? Washington, D.C.: Centerfor Economic and Policy Research. Retrieved from: http://cepr.net/documents/publications/scorecard-201104.pdf

Zhang, X., Yang, J., \& Wang, S. (2010). Chinahas reached the Lewisturning point. IFPRI discussion paper. Washington, D.C: International Food Policy Research Institution.

\section{APPENDIX}

\section{Models' testing (regression models' characteristics)}

For the first cluster model:

\begin{tabular}{|c|c|c|c|c|c|c|}
\hline \multirow[b]{2}{*}{$\mathbf{N}=15$} & $\begin{array}{l}\text { Regression } S \\
R=.7980499 \\
F(1.13)=22.8\end{array}$ & $\begin{array}{l}\text { mmary for Det } \\
\quad R ?=.6368 \\
1 \quad p<00036\end{array}$ & $\begin{array}{r}\text { dent Varia } \\
5 \quad \text { Adjuste } \\
\text { Error o }\end{array}$ & $\begin{array}{l}\text { : HDI }\left(1^{\text {st }} \mathrm{clu}\right. \\
\mathrm{R} ?=.6089517 \\
\text { stimate: } 0.010\end{array}$ & & \\
\hline & $\mathrm{b}^{*}$ & Std. Err. of b* & $\mathrm{b}$ & Std. Err. of b & $\mathrm{t}(13)$ & $\mathrm{p}$-value \\
\hline Intercept & & & 0.647878 & 0.056964 & 11.37345 & 0.000000 \\
\hline E1 & 0.798050 & 0.167129 & 0.306753 & 0.064241 & 4.77506 & 0.000363 \\
\hline
\end{tabular}

For the second cluster model:

\begin{tabular}{|c|c|c|c|c|c|c|}
\hline \multirow[b]{2}{*}{$\mathbf{N}=17$} & $\begin{array}{l}\text { Regression } \mathrm{Su} \\
\mathrm{R}=.53770207 \\
\mathrm{~F}(\mathbf{1 . 1 5})=6.100\end{array}$ & $\begin{array}{c}\text { Imary for Depe } \\
R ?=.28912351 \\
p<.02600\end{array}$ & $\begin{array}{l}\text { endent Variab } \\
1 \quad \text { Adjusted R } \\
\text { Std. Error of }\end{array}$ & $\begin{array}{l}\text { IDI }\left(2^{\text {nd }} \text { clust }\right. \\
24173174 \\
\text { nate: } .02731\end{array}$ & & \\
\hline & $\mathrm{b}^{*}$ & Std Err. of $b^{*}$ & $\begin{array}{l}\mathrm{b} \\
\mathrm{b}\end{array}$ & Std. Err. of b & $t(15)$ & $\mathrm{p}$-value \\
\hline Intercept & & & 0.747326 & 0.045342 & 16.48206 & 0.000000 \\
\hline GDP & 0.537702 & 0.217595 & 0.000003 & 0.000001 & 2.46996 & 0.026000 \\
\hline
\end{tabular}

\begin{tabular}{|c|c|c|c|c|c|c|}
\hline \multirow[b]{2}{*}{$\mathbf{N}=17$} & $\begin{array}{l}\text { Regression Su } \\
R=.66496450 \\
F(1.15)=11.890\end{array}$ & $\begin{array}{c}\text { mmary for Dep } \\
\mathbf{R} ?=.4421777 \\
\mathrm{p}<.00358\end{array}$ & $\begin{array}{l}\text { ndent Varial } \\
\text { Adjustec } \\
\text { Std.Error o }\end{array}$ & $\begin{array}{l}: \text { LPI }\left(2^{\text {nd }} \text { clus }\right. \\
\text { R? = .40498954 } \\
\text { stimate: } 2.551\end{array}$ & & \\
\hline & b- & Std. Err. of b* & $\mathrm{b}$ & Std. Err. of b & $\mathrm{t}(15)$ & $\mathrm{p}$-value \\
\hline Intercept & & & 52.53660 & 4.235818 & 12.40001 & 0.000000 \\
\hline GDP & 0.664964 & 0.192842 & 0.00044 & 0.000129 & 3.44823 & 0.003585 \\
\hline
\end{tabular}

\begin{tabular}{|c|c|c|c|c|c|c|}
\hline \multirow[b]{2}{*}{$\mathbf{N}=17$} & $\begin{array}{l}\text { Regression } \\
\mathbf{R}=.7191689 \\
\mathbf{F}(2.14)=7 .\end{array}$ & $\begin{array}{l}\text { Immary for De } \\
\mathrm{R} ?=.51720394 \\
89 \quad \mathrm{p}<.00611 \\
\end{array}$ & $\begin{array}{l}\text { endent Varia } \\
\text { Adjusted R? } \\
\text { Std. Error of }\end{array}$ & $\begin{array}{l}\text { e: HPI }\left(2^{\text {nd }} \text { clu }\right. \\
.44823308 \\
\text { stimate: } .3895\end{array}$ & & \\
\hline & $\mathrm{b}^{-}$ & Std. Err. of b- & $\mathrm{b}$ & Std. Err. of b & $\mathrm{t}(14)$ & $\mathrm{p}$-value \\
\hline Intercept & & & -0.999206 & 2.274957 & -0.439220 & 0.036548 \\
\hline E1 & 0.418404 & 0.188132 & 6.075056 & 2.731602 & 2.223990 & 0.043114 \\
\hline GDP & 0.521734 & 0.188132 & 0.000055 & 0.000020 & 2.773234 & 0.014947 \\
\hline
\end{tabular}


For the third cluster model:

\begin{tabular}{|c|c|c|c|c|c|c|}
\hline \multirow[b]{2}{*}{$\mathbf{N}=16$} & $\begin{array}{l}\text { Regression } \\
R=.9279448 \\
F(2.13)=40\end{array}$ & $\begin{array}{c}\text { mary for Depe } \\
R ?=.86108167 \\
p<0.00000\end{array}$ & $\begin{array}{l}\text { ndent Varial } \\
\text { Adjusted } \\
\text { Std. Error o }\end{array}$ & $\begin{array}{l}\text { HDI }\left\{3^{\text {rd }} \mathrm{cl}\right. \\
=.83970962 \\
\text { estimate: } .016\end{array}$ & & \\
\hline & $\mathrm{b}-$ & Std. Err. of b' & $\mathrm{b}$ & Std. Err. of b & $\mathrm{t}(13)$ & $\mathrm{p}$-value \\
\hline Intercept & & & 0.494322 & 0.058379 & 8.467501 & 0.000001 \\
\hline E1 & 0.396707 & 0.143352 & 0.274726 & 0.099273 & 2.767369 & 0.015998 \\
\hline GDP & 0.607904 & 0.143352 & 0.000004 & 0.000001 & 4.240641 & 0.000964 \\
\hline
\end{tabular}

For the fourth cluster model:

\begin{tabular}{|c|c|c|c|c|c|c|}
\hline \multirow[b]{2}{*}{$N=16$} & $\begin{array}{l}\text { Regression } \\
R=0.910102 \\
F(2.13)=31\end{array}$ & $\begin{array}{c}\text { nmary for Dep } \\
\text { R? = 0.82828 } \\
\text { p }<.00001\end{array}$ & $\begin{array}{l}\text { dent Varial } \\
\text { Adjuste } \\
\text { d. Error of }\end{array}$ & $\begin{array}{l}\text { HDI }\left(4^{\text {th }} \text { clus }\right. \\
?=0.8018697 \\
\text { mate: } 0.01668\end{array}$ & & \\
\hline & \begin{tabular}{|c|}
$b^{*}$ \\
\end{tabular} & Std. Err. of b* & $\mathrm{b}$ & Std. Err. of b & $\mathrm{t}(13)$ & p-value \\
\hline Intercept & & & 0.491678 & 0.075528 & 6.509875 & 0.000020 \\
\hline EI & 0.299143 & 0.120543 & 0.258080 & 0.103996 & 2.481627 & 0.027526 \\
\hline GDP & 0.774030 & 0.120543 & 0.000005 & 0.000001 & 6.421188 & 0.000023 \\
\hline
\end{tabular}

There were no significant models in the fifth cluster, therefore, they are not given in Table 7.

For the sixth cluster model:

\begin{tabular}{|c|c|c|c|c|c|c|}
\hline \multirow[b]{2}{*}{$\mathrm{N}=21$} & \multicolumn{6}{|c|}{$\begin{array}{l}\text { Regression Summary for Dependent Variable: HDI }\left(6^{\text {th }} \text { cluster }\right) \\
\begin{array}{lll}R=.90059699 & R ?=.81107494 & \text { Adjusted } R ?=.79008327 \\
F(2.18)=38.638 & p<.00000 & \text { Std. Error of estimate: } .02210\end{array}\end{array}$} \\
\hline & $\mathrm{b}^{*}$ & Std. Err. of b* & $\mathrm{b}$ & Std. Err. of b & $\mathrm{t}(18)$ & $\mathrm{p}$-value \\
\hline Intercept & & & 0.350889 & 0.039184 & 8.954926 & 0.000000 \\
\hline E1 & 0.624547 & 0.105647 & 0.434271 & 0.073460 & 5.911646 & 0.000014 \\
\hline GDP & 0.514039 & 0.105647 & 0.000006 & 0.000001 & 4.865632 & 0.000124 \\
\hline
\end{tabular}

For the seventh cluster model:

\begin{tabular}{|c|c|c|c|c|c|c|}
\hline \multirow[b]{2}{*}{$N=9$} & \multicolumn{6}{|c|}{$\begin{array}{l}\text { Regression Summary for Dependent Variable: HDI (all without gap of } 9 \text { indicators) } \\
\begin{array}{lll}\mathrm{R}=.94348274 & \mathrm{R} ?=.89015968 \text { Adjusted } \mathrm{R} ?=.85354623 \\
\mathrm{~F}(2.6)=24.312 & \mathrm{p}<.00133 & \text { Std. Error of estimate: } .03301\end{array}\end{array}$} \\
\hline & $\mathrm{b}^{*}$ & Std. Err. of b* & \begin{tabular}{l|c}
$*$ & $\mathrm{~b}$ \\
\end{tabular} & Std. Err. of b & $\mathrm{t}(6)$ & $\mathrm{p}$-value \\
\hline Intercept & & & 0.557167 & 0.033343 & 16.71031 & 0.000003 \\
\hline Gll & -0.364207 & 0.149807 & -0.145608 & 0.002580 & -1.85697 & 0.000157 \\
\hline GDP & 0.727940 & 0.149807 & 0.000011 & 0.000002 & 4.85918 & 0.002825 \\
\hline
\end{tabular}

\begin{tabular}{|c|c|c|c|c|c|c|}
\hline \multirow[b]{2}{*}{$N=9$} & $\begin{array}{l}\text { Regression } \\
\mathbf{R}=.851911 \\
\mathrm{~F}(1.7)=18.5\end{array}$ & $\begin{array}{c}\text { mmary for Dep } \\
R ?=.725753 \\
p<.00355\end{array}$ & $\begin{array}{l}\text { ent Variab } \\
\text { Adjusted I } \\
\text { ror of esti }\end{array}$ & $\begin{array}{l}\text { EL (all witho } \\
=.68657564 \\
\text { te: } .05417\end{array}$ & ap of 9 ind & \\
\hline & $b^{*}$ & Std. Err. of b* & $\mathrm{b}$ & Std. Err. of b & $\mathrm{t}(7)$ & $\mathrm{p}$-value \\
\hline Intercept & & & 0.456770 & 0.025475 & 17.93014 & 0.000000 \\
\hline GDP & 0.851912 & 0.197934 & 0.000014 & 0.000003 & 4.30401 & 0.003549 \\
\hline
\end{tabular}

\begin{tabular}{|c|c|c|c|c|c|c|}
\hline \multirow[b]{2}{*}{$\mathbf{N}=\mathbf{9}$} & \multicolumn{6}{|c|}{$\begin{array}{l}\text { Regression Summary for Dependent Variable: GDP (all without gap of } 9 \text { indicators } 7^{\text {th }} \text { (1) } \\
\text { claster)) }\end{array}$} \\
\hline & $\mathrm{b}^{*}$ & Std. Err. of b* & $\mathrm{b}$ & Std. Err. of b & $\mathrm{t}(7)$ & $\mathrm{p}$-value \\
\hline Intercept & & & -32418.5 & 15048.17 & -2.05688 & 0.048787 \\
\hline GDP & 0.691415 & 0.273063 & 694.6 & 274.33 & 2.53207 & 0.039115 \\
\hline
\end{tabular}




\begin{tabular}{|c|c|c|c|c|c|c|}
\hline \multirow[b]{2}{*}{$\mathbf{N}=\mathbf{9}$} & \multicolumn{6}{|c|}{ 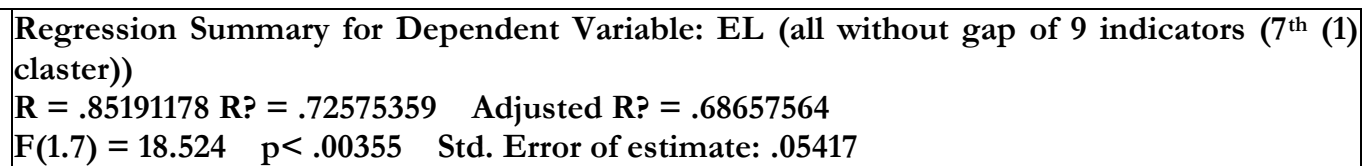 } \\
\hline & $\mathrm{b}^{*}$ & Std. Err. of b* & $\mathrm{b}$ & Std. Err. of b & $\mathrm{t}(7)$ & $\mathrm{p}$-value \\
\hline Intercept & & & 0.456770 & 0.025475 & 17.93014 & 0.000000 \\
\hline GDP & 0.851912 & 0.197934 & 0.000003 & 0.000001 & 4.30401 & 0.003549 \\
\hline
\end{tabular}

For the eighth cluster model:

\begin{tabular}{|c|c|c|c|c|c|c|}
\hline \multirow[b]{2}{*}{$\mathbf{N}=29$} & \multicolumn{6}{|c|}{$\begin{array}{l}\text { Regress ion Summary for Dependent Variable: HDI }\left(8^{\text {th }} \text { cluster }\right) \\
R=.54679745 \quad R ?=.29898745 \text { Adjusted } R ?=.24506341 \\
F(2.26)=5.5446 \quad p<.00987 \text { Std. Error of estimate: } .04663\end{array}$} \\
\hline & $\mathrm{b}^{*}$ & Std. Err. of b* & $\mathrm{b}$ & Std. Err. of b & $\mathrm{t}(26)$ & p-value \\
\hline Intercept & & & 0.331540 & 0.049095 & 6.753079 & 0.000000 \\
\hline E1 & 0.354024 & 0.168128 & 0255923 & 0.121539 & 2.105683 & 0.045043 \\
\hline GDP & 0.347537 & 0.168128 & 0.000011 & 0.000005 & 2.067098 & 0.048815 \\
\hline
\end{tabular}

